January 2008

\title{
Opening the Floodgates: Why America Needs to Rethink Its Borders and Immigration Laws
}

Kevin R. Johnson

\section{Recommended Citation}

Kevin R. Johnson, Opening the Floodgates: Why America Needs to Rethink Its Borders and Immigration Laws, 61 SMU L. REV. 3 (2008)

https://scholar.smu.edu/smulr/vol61/iss1/2

This Foreword is brought to you for free and open access by the Law Journals at SMU Scholar. It has been accepted for inclusion in SMU Law Review by an authorized administrator of SMU Scholar. For more information, please visit http://digitalrepository.smu.edu. 


\title{
Opening the Floodgates: Why America NeEds to Rethink Its BORDERS AND IMMIGRATION LAWS
}

\author{
Kevin R. Johnson*
}

\section{n}

IIME and time again, U.S. immigration law has been well behind global and domestic changes, resulting in numerous laws and incidents that we now regret as a nation. Sadly, the United States is still behind the times. In terms of immigration policy, the nation still lives in a world of kingdoms with moats, walls, and barriers, rather than a modern world of mass transportation, the Internet, and daily international intercourse.

It is a cliché to say that the globalizing economy and technological improvements in communication and transportation have made the world a smaller place. But it is true. Increased trade, movement, and interconnections between nations are much more common now than they have ever been. Many citizens of the modern world have ties to multiple nations. Migrants often have deep ties both to their native countries and to their countries of destination. ${ }^{1}$

To this point, the U.S. immigration laws have responded in rather limited ways to the phenomenon of globalization. Incremental reforms have done little to address the nation's true immigration needs. Similarly, the rights of immigrants have tended to expand over time, but have done so in fits and starts. ${ }^{2}$ After years of consideration, the U.S. government took

* Associate Dean for Academic Affairs, School of Law, University of California, Davis, Mabie-Apallas Professor of Public Interest Law and Chicana/o Studies; A.B., University of California, Berkeley; J.D., Harvard University. This is a slightly adapted excerpt from Kevin R. Johnson, Opening the Floodgates. Why America Needs to ReTHINK ITS BORDERS AND IMMIGRATION LAWS 208-11 (2007). I presented an outline of this book at the Conference on Immigrants, Vigilantes, and Immigration Reform: Civil Rights in the 21st Century at Southern Methodist University Dedman School of Law in October 2007. Thanks to Professor George A. Martínez for inviting me to participate in the conference and for serving as a sounding board for my ideas for many years. Thanks also to SMU Dean John Attanasio for his financial, intellectual, and moral support for the event. I blogged about the conference on the ImmigrationProf blog at http://lawprofessors. typepad.com/immigration/2007/10/scholarly-happe.html.

1. See Kim Barry, Home and Away: The Construction of Citizenship in an Emigration Context, 81 N.Y.U. L. REv. 11, 26-27 (2006); Anupam Chander, Diaspora Bonds, 76 N.Y.U. L. REv. 1005, 1006 (2001); Peter J. Spiro, The Citizenship Dilemma, 51 Stan. L. Rev. 597, 621-25 (1999) (reviewing Rogers M. SMIth, Civic Ideals: Conflicting VISIONS OF CITIZENSHIP IN U.S. History (1997)).

2. See generally Peter $H$. Schuck, The Transformation of Immigration Law, 84 Colum. L. Rev. 1, 35-54 (1984) (documenting pressures for a change to classical immigration law). 
the cautious step of recognizing dual nationality, which quickly grew in popularity among Mexican nationals living in the United States. However, the U.S. immigration laws have failed more generally to respond to the globalizing economy.

Open borders are consistent with the integrating world economy. I have outlined arguments for a far-reaching change in the U.S. immigration laws that would respond to the rapidly changing world in which we live. Open borders would mark a true revolution in current U.S. immigration law and would create an admissions system in which migration more closely approximates demand.

The elimination of exaggerated border controls would offer many benefits to the United States. As part of a globalizing economy, the nation stands to reap economic benefits from freer labor migration. As a matter of economic theory, international trade with Mexico and much of the world-which the United States has eagerly embraced-differs little from labor migration. A utilitarian approach would allow for labor migration and add the benefits of new labor to the national economy.

Importantly, the removal of controls would end the sheer brutality inherent in current immigration enforcement, which results in physical abuse, promotes racial discrimination, and relegates certain groups of U.S. citizens and lawful immigrants to second-class status, both inside and outside the United States. Permeable borders would allow for the admission of immigrants in numbers approximating the demand for immigration and make it unnecessary for many noncitizens seeking entry into the United States to circumvent the law. The immigration laws would not create the need for aggressive enforcement, with its discriminatory impacts and deadly results.

Last but not least, strong policy arguments exist for the abolition of border controls. Experience demonstrates that, at least within modern sensibilities, overzealous border controls simply cannot be enforced by the U.S. government. Undocumented immigration is not viewed as criminal by many law-abiding Americans, ${ }^{3}$ nor is the employment of undocumented immigrants. ${ }^{4}$ Abolition of border controls would recognize the economic and social reality of immigration. Millions of undocumented immigrants make valuable contributions to the U.S. economy but are forced to live on the margins of society and, subject to exploitation because of their uncertain immigration status, work in poor conditions for substandard wages. ${ }^{5}$ Foreign policy benefits would accrue from a system in which nationals of other societies were welcomed rather than labeled a public menace, barred from entry, and treated as pariahs in our midst.

It may well be that "[d]espite the rapid globalization of the world economy, the countries of terra firma are unlikely to abandon the concept of

3. See Catherine L. Merino, Note, Compromising Immigration Reform: The Creation of a Vulnerable Subclass, 98 YALE L.J. 409, 412 (1988).

4. See id.

5. Id. 
individual, sovereign nations in favor of a world of free borders and unrestricted migration." Times have changed, however. It is to be hoped that the time will come when the United States will realize that closed borders are far from inevitable and, in fact, do not serve the national interests. Closed borders result in immoral consequences that, in the annals of history, have shamed the United States and will continue to do so. The Berlin-Wall-lite that the government is in the process of erecting between the United States and Mexico is not consistent with American values and dreams. Rather, an "open Republic" is more consistent with the values for which this nation proudly stands. ${ }^{7}$

Because it is difficult to estimate the impacts of a move to open borders on migration, there are unquestionably risks in moving to a system of open entry. We cannot be certain how many people will take advantage of open entry into the United States, although the available evidence suggests that the nation would not experience a flood of migrants. A transitional program might ease the adjustment and minimize the risks of public disorder. However, the United States' past experience with virtually open borders suggests that a mass migration need not necessarily follow.

The successful European Union (EU) provides the model for a secondbest alternative. Border controls among member states are minimal. ${ }^{8}$ Free migration within the member states has not resulted in mass migrations. ${ }^{9}$ Labor can now move to the location of highest demand and most efficient use. ${ }^{10}$ Growing pains, of course, resulted at the outset, ${ }^{11}$ but the system soon achieved stability and acceptance. ${ }^{12}$ Overall, the move to a common labor market was relatively uneventful.

However, the opening of internal borders in the EU was accompanied by a building of borders at the outer perimeters of the Union. Critics have claimed that a "Fortress Europe" has had negative effects on asylum seekers and created problems like those seen at the U.S. borders. ${ }^{13}$ North Africans seek to enter the EU though Spain by hazarding a dangerous crossing of the Mediterranean Sea. ${ }^{14}$ Migrants die. ${ }^{15}$ Hate crimes against

6. Victor C. Romero, Expanding the Circle of Membership by Reconstruction of the "Alien": Lessons From Social Psychology and the "Promise Enforcement" Cases, 32 U. Mich. J.L. REForm 1, 5 (1998) (footnote omitted).

7. See Jost Delbrück, Global Migration-Immigration-Multiethnicity: Challenges to the Concept of the Nation-State, 2 Ind. J. Global Legal Studies 45, 48 (1994) (offering the idea of an "Open Republic" as an alternative to the conventional wisdom of nation-states with closed borders).

8. See Frigyes Ferdinand Heinz \& Melanie Ward-Warmedinger, Cross-Border Labour Mobility Within an Enlarged EU, Occasional PaPer Series, Oct. 2006, at 1, 8.

9. Id. at 11 .

10. Id. at 8 .

11. Id. at $8-9$.

12. Id. at 9.

13. See Press Release, Amnesty International, The Human Cost of "Fortress Europe": Asylum Seekers Unfairly Detained and Unfairly Expelled (June 20, 2005).

14. Id.

15. Henrique Almelda \& Ingrid Melander, EU, Africa Spar Over Illegal Immigration, Reuters, Dec. 8, 2007. 
immigrants have risen with disturbing frequency in the EU nations. ${ }^{16}$ In 2005, social strife resulted in France as Muslims protested their secondclass status in French society. The problems experienced in Fortress Europe suggest that a "North American Union" is a second-best alternative to more generally permeable borders.

In the end, the politics for any true immigration reform effort will be challenging. Many reform proposals have been made by politicians and academics, but political support has not been forthcoming. ${ }^{17}$ Nonetheless, the issue of immigration-and, more importantly, immigrants-is not going away. Indeed, as the United States remains the last true superpower and immigration has become a global phenomenon, it is increasing in importance. Economic globalization means that world migration is here to stay. As a nation, we can no longer fool ourselves by pretending migrants will go away or listen if we tell them they are not welcome. ${ }^{18}$

Ultimately, migration of people is inevitable. The United States must make an important choice. It can have laws that effectively and efficiently regulate admission into the country. Or, it can have laws, like those it currently has, that are inefficient, wasteful, and futile, and that damage the nation.

16. Molly Moore, E.U. Ministers Agree on Rules Against Hate Crime Racism, WAsH. Post Foreign Serv., Apr. 20, 2007, at A25.

17. See, e.g., Douglas S. Massey, Jorge Durand \& Nolan J. Malone, Beyond SMoke and Mirrors: Mexican ImMigration in an Era of Economic Integration $142-64$ (2002).

18. See id. at 3-6. 